\title{
To Facilitate and Protect: State Obligations and the Right of Peaceful Assembly in International Human Rights Law
}

\section{Michael Hamilton}

This article distinguishes between the obligation of States to 'facilitate' and 'protect' the right of peaceful assembly under Article 21 of the International Covenant on Civil and Political Rights (ICCPR) and State practices that rather seek to 'manage' or 'control' its exercise. Focusing on the protection of public assemblies in the Asia-Pacific region and drawing principally on the UN Human Rights Committee's assembly jurisprudence and its Concluding Observations on State reports, it emphasizes the critical importance of the language in which State obligations are framed and understood. Many domestic laws over-regulate the right of assembly by creating broad discretionary powers, impermissible grounds of restriction, bureaucratic procedures and onerous liabilities. Such laws reinforce a police ego-image premised on the pernicious logic of 'management' and encourage preventive policing tactics that fundamentally undermine the right of peaceful assembly.

\section{Keywords}

Article 21 ICCPR - peaceful assembly - State obligations - facilitate and protect - domestic legal framework

\section{Introduction}

As in other parts of the world, the right of peaceful assembly in the Asia Pacific region has been critical to those who seek to gather with others - sometimes privately in homes and meeting rooms and often publicly, to galvanize and bring visibility to their cause. The right has been exercised by those struggling for independence and other forms of political change, those seeking to resist rapacious land grabs and those protesting against environmental degradation, extractive industries and the exploitation of workers' rights. While many gatherings deserving of protection will often have relatively mundane aspirations, the ability to come together with others can stimulate the formation and development of profoundly important social and political identities. As an individual right exercised collectively it is a right that may be especially important to marginalized groups historically excluded from the public realm and whose existence is rendered precarious through (for example) social stigmatization, displacement, conflict, insecure land tenure or the consequences of climate change. In particular, the right of peaceful assembly is a uniquely potent tool through which individuals can oppose established structures of power, even when the social or political context - and limited institutional avenues of redress - makes the status quo seem otherwise immune to challenge.

The challenges involved in ensuring an effective right of peaceful assembly immediately bring into sharp focus the potentially conflicted role of States. The fact that protection ultimately falls to domestic authorities not only highlights the state centricity of international human rights protections, but also raises a tension at the domestic level - the very assemblies that States are obliged to protect may in fact present (or be perceived to present) an existential threat to vested State interests. It is suggested that this tension provides an entry point for a 
pernicious and regulatory logic of assembly 'management'. While ostensibly preferable to openly repressive tactics (and despite the pretence that it is merely concerned with reconciling conflicting interests), a 'management' approach unduly choreographs and corrals the way in which people are able to gather. The language of 'management' connotes 'control', ${ }^{1}$ is intuitively precautionary and is the anathema of spontaneity. ${ }^{2}$ Moreover, it reinforces a police ego-image as servants of the State rather than of the people. As such, its invocation emboldens the police in many problematic aspects of protest policing - blocking access to protesters, ${ }^{3}$ using excessive force, ${ }^{4}$ and adopting pervasive methods of surveillance (both overt and covert) ${ }^{5}$

This article identifies and elaborates some of the key State obligations in international human rights law that aim to ensure an effective right of peaceful assembly. It focuses primarily on the issues disclosed by the UN Human Rights Committee's Concluding Observations on the periodic reports of States specifically within the Asia-Pacific region, arguing that these normative standards - in framing State obligations in the language of 'facilitation' and 'protection' - can be relied upon to challenge and push back against the regulatory logic of 'management'.

The article begins by noting the jurisdictional skew inherent in the Human Rights Committee's assembly jurisprudence and its seeming lack of traction in the Asia-Pacific region. It then turns to examine the key obligation of States to ensure that the domestic legal framework governing the right of peaceful assembly is an enabling one, aimed at the facilitation and protection of the right of peaceful assembly rather than primarily at its control. In this regard, the article further explores (a) the negative and positive obligations that States are duty bound to fulfil (including non-discrimination and the 'sight and sound' principle); (b) the strict requirements of necessity and proportionality applicable to both prior restrictions and subsequent penalties; (c) prior notification requirements as an interference with the right of peaceful assembly; and (d) the permissible grounds of restriction (focusing in particular on restrictions imposed putatively to ensure the flow of 'traffic', and to prohibit the 'advocacy of hatred' under Article 20(2) ICCPR). Finally, the article explores the question of how structural deficiencies in the domestic legal framework might be challenged through international human rights mechanisms.

\footnotetext{
${ }^{1}$ Antoine Buyse, for example, uses the phrase 'manage, control and repress' suggesting that there is little to differentiate between the three verbs. See, A Buyse, 'In Sudan and Hong Kong, protest is changing - and hope is rising', The Guardian, 18 June 2019.

${ }^{2}$ See further, D A Snow and Dana M Moss, 'Protest on the Fly: Toward a Theory of Spontaneity in the Dynamics of Protest and Social Movements' (2014) 79(6) American Sociological Review 1122 (noting, at 1125, the trend in the US and Europe to developing Public Order Management Systems (POMS) with the result that 'demonstrations become increasingly standardized').

${ }^{3} \mathrm{Eg}$ Human Rights Committee 'List of issues in relation to the fourth periodic report of the Republic of Korea', CCPR/C/KOR/Q/4, 28 April 2015, para 26.

${ }^{4}$ Eg Human Rights Committee, 'Concluding observations on the third periodic report of Hong Kong, China' (29 April 2013) UN Doc CCPR/C/CHN-HKG/CO/3, para 11; Human Rights Committee, 'Concluding observations on the initial report of Thailand (8 July 2005) UN Doc CCPR/CO/84/THA, para 24; Human Rights Committee, 'Concluding observations on the second periodic report of Cambodia' (27 April 2015) UN Doc CCPR/C/KHM/CO/2, para 12; Human Rights Committee, 'Concluding observations on the fourth periodic report of the Republic of Korea' (3 December 2015) UN Doc CCPR/C/KOR/CO/4, para 53; Human Rights Committee, 'Concluding observations on the initial report of Indonesia' (21 August 2013) UN Doc $\mathrm{CCPR} / \mathrm{C} / \mathrm{IDN} / \mathrm{CO} / 1$, para 16.

${ }^{5}$ Eg Human Rights Committee, 'Concluding observations on the fourth periodic report of the Republic of Korea' (3 December 2015) UN Doc CCPR/C/KOR/CO/4, paras 42-43; Human Rights Committee, 'Concluding observations on the third periodic report of Hong Kong, China' (29 April 2013) UN Doc CCPR/C/CHN$\mathrm{HKG} / \mathrm{CO} / 3$, para 10; Human Rights Committee, 'Concluding observations on the initial report of Macao, China' (29 April 2013) CCPR/C/CHN-MAC/CO/1, para 16.
} 


\section{General Comment 37 and its neglected jurisprudential base}

While the right of peaceful assembly is rarely far from news headlines, the UN Human Rights Committee's assembly-related jurisprudence - under Article 21 of the International Covenant on Civil and Political Rights (ICCPR), also often engaging the right to freedom of expression under Article 19 - has, until recently, been largely overlooked. ${ }^{6}$ Other than the recognized scholarly commentaries on the Covenant, ${ }^{7}$ it has taken the Committee's initiative to draft General Comment 37 on the right of peaceful assembly to direct a spotlight on the important standards articulated by the Committee through both its views on 'Individual Communications' and its 'Concluding Observations' on periodic State reports. ${ }^{8}$

This body of jurisprudence numbers approximately 100 cases. However, assembly related communications have been submitted by individuals in only 13 of the 193 UN Member States. ${ }^{9}$ Moreover, reflecting a further jurisdictional skew, more than 69 of these communications relate to a single country - Belarus. While the Committee's wide-ranging Concluding Observations compensate somewhat for the distorted pattern of individual complaints (with over 160 'Concluding Observations' on State reports reaching at least 97 Member States),${ }^{10}$ the limited traction of these international standards in the Asia-Pacific region is further compounded by the fact that only eight Asia-Pacific countries (just over one fifth) have ratified the First Optional Protocol to the Covenant. ${ }^{11}$ Only if a country has ratified this Optional Protocol can the Human Rights Committee receive communications from individuals claiming to be victims of a violation of Covenant rights. ${ }^{12}$

\footnotetext{
${ }^{6}$ This article draws extensively on a preliminary study submitted to the UN Human Rights Committee in advance of its half-day discussion on General Comment 37 on 20 March 2019. See, M Hamilton, 'Towards General Comment 37 on Article 21 ICCPR: The Right of Peaceful Assembly'. The study was generously supported by the 'Greater protection and standard setting at the United Nations' project, managed by the European Center for Not-for-Profit Law (ECNL), made possible by the International Center for Not-for-Profit Law (ICNL) through the Civic Space Initiative and financed by the Government of Sweden.

${ }^{7}$ W A Schabas, UN International Covenant on Civil and Political Rights: Nowak's CCPR Commentary $\left(3^{\mathrm{rd}} \mathrm{edn}\right.$, N.P. Engel, 2019); S Joseph and M Castan, The International Covenant on Civil and Political Rights: Cases, Materials, and Commentary ( $3^{\text {rd }}$ edn, OUP 2013).

${ }^{8}$ See further, M Hamilton, 'The Right of Peaceful Assembly - The Meaning and Scope of 'Assembly' in International Human Rights Law' (forthcoming, ICLQ).

${ }^{9}$ In rank order: Belarus (69), Russia (6), Kazakhstan (4), Algeria (3), Australia (3), Libya (2), Netherlands (2), Paraguay (2), Uzbekistan (2), Canada (1), Finland (1), Republic of Korea (1), Azerbaijan (1). Further research is needed to explain this distorted pattern of assembly-related complaints, exploring the obstacles and disincentives to submitting complaints to the Human Rights Committee (including those that may relate to the exhaustion of domestic remedies as required by Article 5(2)(b) of the first Optional Protocol).

${ }^{10}$ The 'Library of UN and Regional Materials on Freedom of Assembly' developed in the course of this research can be found at: 〈https://sites.google.com/view/icnl-unhrc-foa-library/home>

${ }^{11}$ Australia, Maldives, Mongolia, Nepal, New Zealand, Philippines, Republic of Korea, and Sri Lanka. A further two countries - Cambodia and Nauru - are signatories but have not ratified the Optional Protocol. Globally, a total of 116 States have ratified the Optional Protocol (including approximately a third of both African and Latin American countries).

12 The precise boundaries of the Asia-Pacific region are not firmly established. Nonetheless, twenty-four of thirty-nine countries in the Asia-Pacific region have ratified the ICCPR. These are: Australia, Bangladesh, Cambodia, Democratic Peoples' Republic of Korea, Fiji, India, Indonesia, Japan, Lao, Maldives, Marshall Islands, Mongolia, Nepal, New Zealand, Papua New Guinea, Pakistan, Philippines, Republic of Korea, Samoa, Sri Lanka, Thailand, Timor-Leste, Vanuatu, and Vietnam. In addition, three countries - China, Nauru and Palau - are signatories to the Covenant but have not yet ratified it. Twelve Asia-Pacific countries have not yet ratified the ICCPR including four of the ten ASEAN Member States - Brunei Darussalam, Malaysia, Myanmar and Singapore - plus Bhutan and seven Oceania countries: Cook Islands, Kiribati, Micronesia, Niue, Solomon Islands, Tonga and Tuvalu.
} 
The drafting of a General Comment on the right of peaceful assembly has long been advocated - both to bring greater coherence to the Committee's consideration of this right, and to provide an authoritative interpretative guide for States to the key legal norms. ${ }^{13}$ The process of drafting General Comment 37 on Article 21 ICCPR was finally begun by the Committee in November 2018 and is due to be completed by the end of $2020 .{ }^{14}$ A General Comment must transcend both jurisdictional particularities and present-day concerns in order to clarify for States their obligations and provide a point of reference for the Committee in its future work.

Significant efforts have been made - especially by the Committee's Rapporteur for the General Comment, Professor Christof Heyns - to ensure that the drafting process is underpinned by an inclusive consultative process. Notably, the first two drafts of General Comment 37 contained extensive references to regional sources - a practice that has been critiqued not only on the basis that it might dilute the Committee's perceived authority, but also that it could further exacerbate the normative disconnect with the General Comment for countries in the Asia Pacific region. ${ }^{15}$ On the one hand, there has been an impressive level of engagement from human rights Non-Governmental Organizations (NGOs) in the Asia-Pacific region (broadly defined) - in particular, from NGOs based in Hong Kong, ${ }^{16}$ South Korea, ${ }^{17}$ Japan, ${ }^{18}$ Sri Lanka ${ }^{19}$ and Thailand. ${ }^{20}$ On the other hand, however, no States from the Eastern Asia-Pacific region made a formal submission on the draft text of General Comment $37 .^{21}$ Indeed, of the 25 National Human Rights Institutions (NHRIs) that are member or associate members of the Asia Pacific Forum, only two of these - the NHRIs of the Philippines ${ }^{22}$ and of India $^{23}$ - made submissions to the Committee.

The lack of traction of international human rights law in the Asia-Pacific region is undoubtedly compounded by the lack of an ASEAN regional mechanism capable of scrutinizing the restrictions imposed on the right of peaceful assembly and developing an

\footnotetext{
${ }^{13}$ Eg Wilton Park Conference Report, 'Peaceful protest: a cornerstone of democracy: How to address the challenges?' 26-28 January 2012 (WP1154), p 2, para 5: 'There is broad agreement that the Committee should now do so as a priority.' Available at <https://www.wiltonpark.org.uk/wp-content/uploads/wp1154-report.pdf>. 14 'Human Rights Committee closes one hundred and twenty-fourth session in Geneva', 2 November 2018. Available at <https://www.ohchr.org/EN/NewsEvents/Pages/DisplayNews.aspx?NewsID=23824\&LangID=E> ${ }^{15}$ Evelyn Aswad, 'The Use of Regional Jurisprudence in UN Draft General Comment on the Freedom of Assembly', Just Security (7 February 2020); Gerald Neuman, 'The Draft General Comment on Freedom of Assembly: Might Less Be More?' (4 February 2020).

${ }^{16}$ Separate submissions were made by Demosistō; the Legislative Council Office of Dennis Kwok (Civic Party, HKSAR); the Hong Kong Bar Association (HKBA); the Justice Centre Hong Kong; and a further coalition of Hong Kong NGOs (led by Hong Kong Human Rights Monitor and Civil Rights Observer and also including Civil Human Rights Front, Demosistō, Law Lay Dream, and Mission for Migrant Workers).

${ }^{17}$ From the Republic of Korea, submissions were made by MINBYUN (Lawyers for a Democratic Society

Public Interest and Human Rights Litigation Center) and Open Net Korea.

${ }^{18}$ From Japan, a submission was made by the NGO, 'Stand with Okinawa'.

${ }^{19}$ The Centre for Policy Alternatives (CPA).

${ }^{20}$ A submission was made by a coalition of Thai Civil Society Organizations (supported by the Geneva based CCPR Centre). This coalition comprised: Thai Lawyers for Human Rights (TLHR), ENLAWTHAI Foundation (EnLAW), Internet Law Reform Dialogue (iLaw), Human Rights Lawyers Association (HRLA), Community Resource Centre Foundation (CRC), and the Legal Research and Development Center, Faculty of Law, Chiang Mai University (LRDC).

${ }^{21}$ If however, the Asia-Pacific region is considered to extend further into Central and Western Asia (according, for example, to the twenty-five national human rights institutions that are members or associate members of the Asia Pacific Forum, <https://www.asiapacificforum.net/>), submissions were submitted by State parties of Kyrgyzstan (Central Asia) and by Qatar and Jordan (Western Asia). For the list of submissions, see 〈https://www.ohchr.org/EN/HRBodies/CCPR/Pages/GCArticle21.aspx>

${ }^{22}$ Available at:

<https://www.ohchr.org/Documents/HRBodies/CCPR/GCArticle21/NHRI_Philippines_Commission_on_Huma n_Rights_PH.docx $>$

${ }^{23}$ Available at: 〈https://www.ohchr.org/Documents/HRBodies/CCPR/GC37/NHRI_India_NHRC.docx>
} 
assembly jurisprudence of its own. ${ }^{24}$ This is in marked contrast to the extensive work undertaken, specifically in relation to the right of peaceful assembly, by other regional mechanisms of human rights protection. In particular, the European Court of Human Rights has been at the forefront of developing standards for the protection of the right of peaceful assembly. ${ }^{25}$ In addition, the Organization for Security and Co-Operation in Europe (OSCE) whose 57 Participating States include Mongolia (since 2012) as well as the five Central Asian countries of Kazakhstan, Kyrgyzstan, Tajikistan, Turkmenistan and Uzbekistan - has published Guidelines on the Right of Peaceful Assembly. ${ }^{26}$ Similarly too, both the African Commission for Human and Peoples' Rights ${ }^{27}$ and the Inter-American Commission on Human Rights ${ }^{28}$ have published regionally specific documents that seek to provide guidance for those who seek to exercise the right of peaceful assembly and a normative steer for States in facilitating and protecting the right.

\section{The Pernicious Logic of 'Managing Assemblies'}

The language of assembly 'management' has found favour in the literature on public order policing ('negotiated management' often being celebrated as a 'milder' alternative to 'escalated force' policing, characterized by 'under-enforcement' of the law and lauded as an approach that seeks to 'work with crowds, rather than against them'). ${ }^{29}$ In addition, the language of 'proper management' featured in the title of an important joint report on the right of peaceful assembly by two UN Special Rapporteurs, ${ }^{30}$ and has continued to be used by the UN Special Rapporteur on the Rights to Freedom of Peaceful Assembly and of Association as a generic heading in country visit reports (to refer broadly to police practices). ${ }^{31}$ Language referring the management of assemblies also appears in the draft text of General Comment No $37 .{ }^{32}$

\footnotetext{
${ }^{24} \mathrm{cf}$ the ASEAN Intergovernmental Commission on Human Rights (AICHR). See further <https://aichr.org/> Note too, the Final Declaration of the Regional Meeting for Asia for the World Conference on Human Rights (the 'Bangkok Declaration') adopted by the Ministers and Representatives of Asian States Meeting in Bangkok (29 March - 2 April 1993) which expresses (para 5) an aversion to the use of human rights as an instrument of political pressure. Available at: <www.hurights.or.jp/archives/other_documents/section1/1993/04/finaldeclaration-of-the-regional-meeting-for-asia-of-the-world-conference-on-human-rights.html >

${ }^{25}$ European Court of Human Rights, Guide on Article 11 of the European Convention on Human Rights (November 2019). Available at: 〈https://www.echr.coe.int/Documents/Guide_Art_11_ENG.pdf〉

${ }^{26}$ OSCE/ODIHR - Venice Commission Guidelines on Freedom of Peaceful Assembly (2 ${ }^{\text {nd }}$ edn 2010). Available at: <https://www.osce.org/odihr/73405?download=true> See also, N Jarman and M Hamilton, 'Protecting Peaceful Protest: The OSCE/ODIHR and Freedom of Peaceful Assembly' (2009) 1(2) Journal of Human Rights Practice 208.

${ }^{27}$ African Commission on Human and Peoples' Rights, Guidelines on Freedom of Association and Assembly in Africa (2017) <https://www.achpr.org/legalinstruments/detail?id=5>

${ }^{28}$ Office of the Special Rapporteur for Freedom of Expression of the Inter-American Commission on Human Rights (IACHR), Protest and Human Rights: Standards on the rights involved in social protest and the obligations to guide the response of the State (2019). Available at: <http://www.oas.org/en/iachr/expression/publications/Protesta/ProtestHumanRights.pdf>

${ }^{29}$ Report of the Special Rapporteur on extrajudicial, summary or arbitrary executions, Christof Heyns, on the legal norms applicable to the use of lethal force during demonstrations (23 May 2011) UN Doc A/HRC/17/28, paras 109-115.

${ }^{30}$ UN Doc A/HRC/31/66, 'Joint report of the Special Rapporteur on the rights to freedom of peaceful assembly and of association and the Special Rapporteur on extrajudicial, summary or arbitrary executions on the proper management of assemblies.'

${ }^{31}$ UN Doc A/HRC/32/36/Add.2 Report of the Special Rapporteur on the rights to freedom of peaceful assembly and of association on his mission to the Republic of Korea, Section 3 'Management of Assemblies', paras 3138 .

${ }^{32}$ Revised Draft of General Comment No 37 (November 2019), paragraphs 32, 33 and 71.
} 
While sometimes well-intentioned (indeed, its declared purpose has been stated as the facilitation, rather than frustration, of demonstrations), ${ }^{33}$ the ordinary use of the term 'manage' more closely approximates to 'control'. ${ }^{34}$ As such, the use of the term 'managing' or 'management of' assemblies improperly characterizes the obligations and role of State authorities. While the primary role of the State is to 'respect and ensure' and 'to facilitate the exercise of the right and to protect the participants', 'management' is more closely aligned with 'control' and may unduly reinforce policing practices (and a police 'ego-image') that affords insufficient protection to the essence of the right. Indeed, it may often render the right of peaceful assembly contingent on asymmetrical negotiations between protesters and the police - negotiations that take place 'in the shadow of the law' and lack any of the procedural safeguards (including administrative or judicial review) that might be available in relation to formally imposed legal restrictions. ${ }^{36}$

\section{An Enabling Legal Framework: 'Guided by the objective to facilitate the right' ${ }^{37}$}

Notwithstanding the fact that 180 of the 193 UN Member States recognize the right of assembly in their national constitutions, ${ }^{38}$ protection gaps relating to the right of peaceful assembly often stem from deficiencies in the domestic legal framework. ${ }^{39}$ Laws in many countries (in the AsiaPacific region and beyond) confer unfettered discretionary powers on local officials and law enforcement personnel enabling arbitrary, discriminatory and disproportionate restrictions. A cumulative chilling effect often results from the wider matrix of laws that might conceivably give rise to liability for those who organize or participate in assemblies (including the criminal law $^{40}$ and emergency laws or national security legislation) ${ }^{41}$

\footnotetext{
${ }^{33} \mathrm{UN}$ Doc A/HRC/31/66, para 109.

${ }^{34}$ The language of 'control' has itself been used by the Human Rights Committee, 'Concluding observations on the initial periodic report submitted by the Maldives' (31 August 2012) UN Doc CCPR/C/MDV/CO/1, para 23: the State 'should adopt procedures and regulations in compliance with human rights standards for the police in controlling large crowds of protestors' (emphasis added).

${ }^{35}$ Revised Draft of General Comment No 37 (November 2019), paragraphs 8, 24, and 26-27.

${ }^{36}$ See, for example, PAJ Waddington, 'Negotiating Protest: policing by consent?', chapter 4 in Liberty and Order: Public Order Policing in a Capital City (UCL Press 1994); J Gilmore, W Jackson and H Monk, "“That is not facilitating protest. That is dismantling protest"': Anti-fracking protesters' experiences of dialogue policing and mass arrest' (2019) 29(1) Policing \& Society 36; H Gorringe, M Rosie, D Waddington, and M Kominou, 'Facilitating ineffective protest? The policing of the 2009 Edinburgh NATO protests' (2012) 22(2) Policing \& Society 115-132; H Gorringe and M Rosie, 'It's a long way to Auchterarder! "Negotiated management" and mismanagement in the policing of G8 protests' (2008) 59(2) B J Sociology 187-205 (2008); M Wahlstrom and M Oskarsson, 'Negotiating Political Protest in Gothenburg and Copenhagen', Chapter 6 in della Porta, Donatella (ed) The Policing of Transnational Protest (Ashgate 2006) 117-143.

${ }^{37}$ Eg Kim v Uzbekistan, Views adopted 4 April 2018, UN Doc CCPR/C/122/D/2175/2012, para 13.4.

${ }^{38}$ Draft General Comment No. 37 prepared by the Committee's Rapporteur, Christof Heyns, fn 3. <https://www.ohchr.org/EN/HRBodies/CCPR/Pages/GCArticle21.aspx>

${ }^{39}$ Notable in terms of documenting regional examples of bad practice is the civil society led report published by Forum-Asia: 'Instruments of Repression: A Regional Report on the Status of Freedoms of Expression, Peaceful Assembly, and Association in Asia - A Report on Repressive Laws in Asia' (2018), 94-103. Available at: <https://www.forum-asia.org/uploads/wp/2019/02/Instruments-of-Repressions-final-edited.pdf>

${ }^{40}$ Human Rights Committee, 'Concluding observations on the initial report of the Lao People's Democratic Republic (23 November 2018) UN Doc CCPR/C/LAO/CO/1, paras 33-34.

${ }^{41}$ Human Rights Committee, 'Concluding observations on the second periodic report of Thailand' (25 April 2017) UN Doc CCPR/C/THA/CO/2, para 40 (restrictions that do not respond to the requirements under Article 4 of the Covenant); Human Rights Committee, 'Concluding observations on the third periodic report of Hong Kong, China' (29 April 2013) UN Doc CCPR/C/CHN-HKG/CO/3, para 14 (broad definition of the offences of treason and sedition in the Crimes Ordinance); Keun-Tae Kim v Republic of Korea, Views adopted 3 November 1998, UN Doc CCPR/C/64/D/574/1994, para 12.3 ' ... broad and unspecific terms in which the offence under the National Security Law is formulated.'
} 
Deficiencies in the legal framework governing assemblies create openings for a logic of management and control to take root. These structural deficiencies underlie many of the obstacles confronting those who seek to exercise the right, and may be especially pronounced in contexts where cultural norms discourage confrontation with the State. ${ }^{42}$ As Lynette Chua has argued in respect of Singapore, 'obedience to formal law earns cultural legitimacy, whereas disobedience loses it' ${ }^{43}$ Thus, where societal norms value compliance and stability, specific legal provisions (and the illegitimacy of their transgression) will fundamentally shape the nature of contentious politics on the street, as well as the level of both popular and elite support that such actions might enjoy. It is against this backdrop that attention now turns to the State's obligations concerning the domestic legal framework.

In guaranteeing the effective enjoyment of the right of peaceful assembly, the Human Rights Committee has concluded that States should 'take appropriate measures to guarantee in law and in practice, and to create an environment conducive to, the exercise of the rights to freedom of expression, peaceful association and assembly'. ${ }^{44}$ This includes an obligation of non-discrimination (the Committee having highlighted many examples of discriminatory regulation of the right of peaceful assembly). ${ }^{45}$ Indeed, the Committee has expressly stated that laws restricting the rights enumerated in Article 19(2) - and presumably, by extension, Article 21 as well - '... must also themselves be compatible with the provisions, aims and objectives of the Covenant, including the non-discrimination provisions of the Covenant. ${ }^{46}$

\section{Negative obligations of non-interference}

Some countries in the Asia Pacific region subject even the smallest of gatherings to regulation. ${ }^{47}$ However, as a starting point, many forms of assembly ought to be able to take place without any form of regulation at all. In other words, not all 'assemblies' falling within the protective scope of Article 21 should, for that reason, be subjected to regulation. The Human Rights Committee has emphasized this negative obligation of non-interference as follows:

'Just as States parties to the Covenant must adopt legislative measures to give effect to rights, they also bear a negative obligation, deriving from Article 2,

\footnotetext{
${ }^{42}$ L J Chua, 'Pragmatic Resistance, Law, and Social Movements in Authoritarian States: The Case of Gay Collective Action in Singapore' (2012) 46(4) Law \& Society Review 713 at 729.

43 ibid 714.

${ }^{44}$ Eg Human Rights Committee, 'Concluding observations on the initial report of Djibouti' (19 November 2013) UN Doc CCPR/C/DJI/CO/1, para 12(a); Human Rights Committee, 'Concluding observations on the sixth periodic report of Spain' (14 August 2015) UN Doc CCPR/C/ESP/CO/6, para 25. See also, Revised Draft of General Comment No. 37 (November 2019), para 27.

${ }^{45}$ Eg Human Rights Committee, 'Concluding observations on the sixth periodic report of Mongolia' (22 August 2017) UN Doc CCPR/C/MNG/CO/6, paras 11-12 (persons belonging to the lesbian, gay, bisexual, transgender and intersex community); Human Rights Committee, 'Concluding observations on the fifth periodic report of Sri Lanka' (21 November 2014) CCPR/C/LKA/CO/5, paras 22-23 (the Tamil minority). Human Rights Committee, 'List of issues prior to submission of the fifth periodic report of the Republic of Korea' (21 August 2019) UN Doc CCPR/C/KOR/QPR/5*, para 25 (restrictions on the right to peaceful assembly of lesbian, gay, bisexual, transgender and intersex persons)'; Human Rights Committee, 'Concluding observations on the initial report of Indonesia' (21 August 2013) UN Doc CCPR/C/IDN/CO/1, para 27 (Ahmadiyya religious group prevented from holding national conferences).

${ }^{46}$ Fedotova $v$ Russian Federation, Views adopted 31 October 2012, UN Doc CCPR/C/106/D/1932/2010, paras 10.4 and 12.

${ }^{47}$ Eg Human Rights Committee, 'Concluding observations on the second periodic report of Thailand' (25 April 2017) UN Doc CCPR/C/THA/CO/2, para 39 (criticizing the 'strict banning of any public gathering of more than five people and political gatherings of more than four people'). See also, L J Chua and D Gilbert, 'Sexual Orientation and Gender Identity Minorities in Transition: LGBT Rights and Activism in Myanmar' (2015) 37 Hum Rts $Q 1$ at 9-10.
} 
paragraph 2, not to adopt legislative measures which violate the Covenant; if it does so, the State party commits per se a violation of the obligations laid down in article 2, paragraph $2{ }^{\prime} \cdot{ }^{48}$

Limiting the reach of regulation can have very significant effects on the ability of people to come together and the ways in which they choose to do so. To take just one example, Lynette Chua has documented how the enactment of a new law in Singapore exempting indoor public talks from licencing enabled gay activism to organize a month of pride events and 'to test the limits of speaking out. ${ }^{49}$ An emphasis on this negative obligation of non-interference must lie at the heart of an enabling legal framework.

\section{Positive obligations to facilitate and protect}

The UN Human Rights Committee in its Concluding Observations has variously emphasized that States have an obligation to 'guarantee',50 'safeguard',51 'promote',52 'ensure',53 'facilitate' ${ }^{54}$ and 'protect' 55 assemblies. The draft text of General Comment 37 frames the overarching obligation of States as being to 'respect and ensure' the right of peaceful assembly, and within this recognizes the obligation of States to both facilitate and protect assemblies. ${ }^{56}$

In terms of facilitation, the Committee has emphasized that ' $[t]$ he organizers of an assembly generally have the right to choose a location within 'sight and sound' of their target audience'. ${ }^{57}$ As such, while the designation of locations where assemblies can be held without prior authorization (such as Hong Lim park in Singapore ${ }^{58}$ or the 'Agitation Site' in Colombo) ${ }^{59}$ might be viewed as a welcome relaxation of the requirements required to assemble in other locations, if these designated sites become the only places in which assemblies can, in practice, be held, then the right of peaceful assembly is seriously imperilled. ${ }^{60}$ International human rights

\footnotetext{
${ }^{48}$ Tulzhenkova v Belarus, Views adopted 26 October 2011, UN Doc CCPR/C/103/D/1838/2008, individual opinion of Mr Fabián Salvioli, para 7.

${ }^{49}$ L J Chua, 'Pragmatic Resistance, Law, and Social Movements in Authoritarian States: The Case of Gay Collective Action in Singapore' (2012) 46(4) Law \& Society Review 734.

${ }^{50}$ Eg Human Rights Committee, 'Concluding observations on the second periodic report of Thailand' (25 April 2017) UN Doc CCPR/C/THA/CO/2, para 40; Human Rights Committee, 'Concluding observations on the initial report of the Lao People's Democratic Republic (23 November 2018) UN Doc CCPR/C/LAO/CO/1, para 34.

${ }^{51}$ Eg Human Rights Committee, 'Concluding observations on the seventh periodic report of El Salvador' (9 May 2018) UN Doc CCPR/C/SLV/CO/7, para 38.

${ }^{52}$ Eg Human Rights Committee, 'Concluding observations on the second periodic report of Benin' (23 November 2015) CCPR/C/BEN/CO/2, para 33.

${ }^{53}$ Eg Human Rights Committee, 'Concluding observations on the initial report of Indonesia' (21 August 2013) UN Doc CCPR/C/IDN/CO/1, para 28; Human Rights Committee, 'Concluding observations on the fourth periodic report of the Republic of Korea' (3 December 2015) UN Doc CCPR/C/KOR/4, para 53.

${ }^{54}$ Eg Human Rights Committee, 'Concluding observations on the third periodic report of Serbia' (10 April 2017) UN Doc CCPR/C/SRB/CO/3, paras 38-39.

${ }^{55}$ Eg Human Rights Committee, Concluding observations on the third periodic report of Viet Nam (29 August 2019) UN Doc CCPR/C/VNM/CO/3, para 48.

${ }^{56}$ See generally, Revised Draft of General Comment No 37 (November 2019), paras 24-39.

${ }^{57}$ Eg Turchenyak et al v Belarus, Views adopted 10 September 2013, UN Doc CCPR/C/108/D/1948/2010, para 7.4. In Fedotova v Russian Federation, Views adopted 31 October 2012, UN Doc CCPR/C/106/D/1932/2010, para 10.8, the Committee found a violation of article 19 'even if indeed, as argued by the State party, [the author] intended to engage children in the discussion of issues related to homosexuality'.

${ }^{58}$ L J Chua, 'Pragmatic Resistance, Law, and Social Movements in Authoritarian States: The Case of Gay Collective Action in Singapore' (2012) 46(4) Law \& Society Review 713 at 717.

${ }^{59}$ Centre for Policy Alternatives (CPA), 'Brief Submission' (February 2020), available at: <https://www.ohchr.org/Documents/HRBodies/CCPR/GCArticle21/NGO_CentreforPolicyAlternatives.pdf> ${ }^{60}$ The Committee has phrased its concerns in relation to pre-determined protest locations with varying degrees of conviction - (a) 'raises serious doubts as to the necessity of such regulation'; (b) does 'not appear to meet the standards of necessity and proportionality', and (c) 'unduly limits the rights to freedom of assembly'. See
} 
standards go further than merely requiring that States do not relegate assemblies to remote areas where they cannot capture public attention. ${ }^{61}$ Instead, the 'sight and sound' principle casts the State obligation to facilitate assemblies as being about giving effect to the organizer's spatial and auditory preferences, and is vital in terms of ensuring the effectiveness of the right of peaceful assembly. ${ }^{62}$

Also bearing on the nature of 'facilitation', the Committee has been critical of attempts by States to transfer the financial costs associated with holding assemblies to assembly organisers. ${ }^{63}$ On this basis, the draft text of General Comment 37 emphasizes that any requirement for organizers or participants to cover the costs of policing, security, medical assistance or cleaning-up 'are generally not compatible with Article 21. Rather, these costs should as a rule be covered by public funds and should not be transferred to the participants. ${ }^{64}$

In relation then to protection, States 'have a duty to protect the participants in ... a demonstration in the exercise of their rights against violence by others' ${ }^{65}$ This includes providing protection from violent counter-demonstrators and entails a duty to investigate any attacks on those peacefully assembling and to prosecute those responsible. The Committee has noted in particular the State's obligation to protect assembly participants from sexual and gender-based violence, ${ }^{66}$ and these protection imperatives may be especially salient in relation to groups most at risk. ${ }^{67}$

\section{The strict tests of necessity and proportionality}

The Committee has repeatedly sought to highlight excessive, and sometimes unlawful, restrictions on the right to freedom of peaceful assembly, ${ }^{68}$ emphasizing that restrictions 'must

respectively, (a) Levinov v Belarus, Views adopted 19 July 2012, UN Doc CCPR/C/105D/1867/2009, 1936, 1975, 1977-1981, 2010/2010, para 10; (b) Misnikov v Belarus, Views adopted 14 July 2016, UN Doc CCPR/C/117/D/2093/2011 para 9.3; and (c) Sudalenko v Belarus, Views adopted 28 December 2015, UN Doc CCPR/C/115/D/2016/2010, para 8.6.

${ }^{61}$ Eg Human Rights Committee, 'Concluding Observations on the initial report of Kazakhstan' (19 August 2011) UN Doc CCPR/C/KAZ/CO/1, para 26 (concern regarding 'undue restrictions ... such as the designation of areas for holding assemblies, which are routinely located in the outskirts of city centres in order to attract low public attention.')

${ }^{62}$ Eg, in Praded v Belarus, Views adopted 10 October 2014, UN Doc CCPR/C/112/D/2029/2011, para 3.1, the author argued that 'holding the demonstration at any other location [than in front of the Iranian Embassy in Minsk] would have defeated its purpose' (emphasis added).

${ }^{63}$ Eg Human Rights Committee, 'Concluding observations on the fourth periodic report of Switzerland' (22 August 2017) UN Doc CCPR/C/CHE/CO/4, para 48.

${ }^{64}$ Revised Draft General Comment No 37 (November 2019), para 74.

${ }^{65}$ Communication No. 1873/2009, Alekseev v The Russian Federation, Views adopted 25 October 2013, para 9.6. Also, Human Rights Committee, 'Concluding observations on the initial report of Indonesia' (21 August 2013) UN Doc CCPR/C/IDN/CO/1, para 28 ('protesters from harassment, intimidation and violence').

${ }^{66}$ Human Rights Committee in relation, for example, to Chile: Human Rights Committee, 'Concluding observations on the sixth periodic report of Chile' (13 August 2014) UN Doc CCPR/C/CHL/CO/6, para 19 ('allegations about the police committing acts of sexual violence against girls and women during student protests'). Similar concerns in the Asia Pacific region have also been raised, for example, by Amnesty International in relation to Hong Kong. See, 'Sexual violence against Hong Kong protesters - what's going on?' (20 December 2019), available at <https://www.amnesty.org/en/latest/news/2019/12/sexual-violence-againsthong-kong-protesters/>

${ }^{67}$ Eg Human Rights Committee, 'Concluding Observations on the sixth periodic report of Mongolia' (22 August 2017) UN Doc CCPR/C/MNG/CO/6, para 11.

${ }^{68}$ Eg Human Rights Committee, 'Concluding observations on the third periodic report of Vietnam' (29 August 2019) UN Doc CCPR/C/VNM/CO/3, para 47; Human Rights Committee, 'Concluding observations on the initial report of Indonesia’ (21 August 2013) UN Doc CCPR/C/IDN/CO/1, para 28. 
conform to strict tests of necessity and proportionality' ${ }^{69}$ and that this 'is for the State party to demonstrate. ${ }^{70}$ Proportionality has been conceived in terms of overbreadth and least restrictive means: '[A]ny restriction on the freedom of expression must not be overbroad in nature, that is, it must be the least intrusive among the measures that might achieve the relevant protective function and proportionate to the interest whose protection is sought. ${ }^{, 71}$

Legislation also often imposes (or makes possible) blanket prohibitions on assemblies in certain places or at certain times. In a number of Concluding Observations, the Human Rights Committee has been highly critical of such blanket restrictions, ${ }^{72}$ observing that a "wholesale ban on demonstrations is not, in the Committee's opinion, compatible with the right to freedom of assembly under Article 21',73

Legislation also establishes the range of offences that might be imposed on assembly participants ${ }^{74}$ and the corresponding penalties that attach to them. The Committee's jurisprudence contains a number of examples of disproportionate sentences. In Coleman $v$ Australia, for example, the author delivered a public address without a permit. He was fined and after failing to pay the fine, was then held in custody for five days. The Committee considered that this response to the author's conduct was disproportionate. ${ }^{75}$ In a similar vein, in Kim v Uzbekistan (2018) the arrest of a pensioner and imposition of a fine of several monthly wages 'for simply protesting and expressing her views' was not deemed proportionate to the interest it sought to protect. ${ }^{76}$

The Committee in its Concluding Observations has often raised specific concerns about the sanctions sometimes imposed - including, 'revocation of citizenship', ${ }^{77}$ deportation, ${ }^{78}$ suspension and/or expulsion of students, ${ }^{79}$ and bail conditions and similar future bindings (not

\footnotetext{
${ }^{69}$ Stambrovsky v Belarus, Views adopted 24 October 2014, UN Doc CCPR/C/112/D/1987/2010, para 7.3 (emphasis added) citing General Comment No 34, para 22.

${ }^{70}$ Eg Olechkevitch v Belarus, Views adopted 18 March 2013, UN Doc CCPR/C/107/D/1785/2008, para 8.5; Praded v Belarus, Views adopted 10 October 2014, UN Doc CCPR/C/112/D/2029/2011, para 7.8.

${ }^{71}$ Toregozhina $v$ Kazakhstan, Decision adopted 21 October 2014, UN Doc CCPR/C/112/D/2137/2012, para 7.4, citing General Comment No 34, para 34; Sviridov v Kazakhstan, Views adopted 13 July 2017, UN Doc $\mathrm{CCPR} / \mathrm{C} / 12 \mathrm{D} / 2158 / 2012$, para 10.3 . A number of other cases similarly explain proportionality as 'the least intrusive measure to achieve the purpose sought by the State party and that it was proportionate to the interests the State party sought to protect.' Eg Poliakov v Belarus, Views adopted 17 July 2014, UN Doc CCPR/C/111/D/2030/2011, para 8.3 (also citing General Comment No 34, para 34).

${ }^{72} \mathrm{Eg}$ Human Rights Committee, 'Concluding observations on the second periodic report of the Republic of Korea' (1 November 1999), CCPR/C/79/Add.114, para 18: 'The prohibition of all assemblies on major roads in the capital would appear to be overbroad.'

${ }^{73}$ Levinov v Belarus, Views adopted 19 July 2012, UN Doc CCPR/C/105D/1867/2009, 1936, 1975, 1977-1981, 2010/2010, para 10.3.

${ }^{74}$ Human Rights Committee, 'Concluding observations on the initial report of the Lao People's Democratic Republic' (23 November 2018), UN Doc CCPR/C/LAO/CO/1, 23 November 2018, para 33(a) ('[t]he vague and broadly formulated offences of ... of "gatherings aimed at causing social disorder" (Penal Code, art. 72)'); Concluding observations on the initial report of Macao, China (29 April 2013) UN Doc CCPR/C/CHN$\mathrm{MAC} / \mathrm{CO} / 1$, para 16 (inter alia, spreading 'false or demagogic information that may frighten or unsettle the residents').

${ }^{75}$ Communication No 1157/2003, Coleman v Australia, Views adopted 17 July 2006, CCPR/C/87D/1157/2003, para 7.3.

${ }^{76}$ Communication No. 2175/2012, Kim v Uzbekistan, Views adopted 4 April 2018, CCPR/C/122/D/2175/2012, para 13.8.

${ }^{77}$ Human Rights Committee, 'Concluding observations on the third periodic report of Kuwait' (11 August 2016) UN Doc CCPR/C/KWT/CO/3, para 49;

${ }^{78}$ Human Rights Committee, 'Concluding observations on the sixth periodic report of the Dominican Republic' (27 November 2017) UN Doc CCPR/C/DOM/CO/6, para 31.

${ }^{79}$ Human Rights Committee, 'List of issues to be taken up in connection with the consideration of the third periodic report of the Islamic Republic of Iran’ (17 May 2011) UN Doc CCPR/C/IRN/Q/3, para 27.
} 
to take part in future assemblies). ${ }^{80}$ Moreover, in Melnikov v Belarus (2017), the administrative arrest of the author was held to constitute an arbitrary deprivation of liberty in violation of article 9(1) of the Covenant: '[A]rrest or detention as punishment for the legitimate exercise of the rights as guaranteed by the Covenant, including freedom of opinion and expression and freedom of assembly, is arbitrary. ${ }^{, 81}$

\section{Authorization, Notification and the Spectrum in Between}

Notification requirements are often justified on the basis (and to the extent) that they enable the State to fulfil its positive obligations. Notification is thus argued by States to fulfil a 'traffic light' function, enabling efficient scheduling, the assignment of appropriate resources and the avoidance of 'resource-depleting guessing games'. ${ }^{82}$ While it is sometimes difficult to distinguish between a notification and an authorization (or permit) requirement, the key difference lies in the presumption that a notified assembly can proceed as notified unless the organizer(s) hears to the contrary from the authorities (whereas under an authorization scheme express affirmation is always required).

In line with the negative obligation of non-interference noted previously, the Committee has stated that: 'a requirement to pre-notify a demonstration would normally be for reasons of national security or public safety, public order, the protection of public health or morals or the protection of the rights and freedoms of others.' As such, notification should not automatically be required for all assemblies - for example, those with only two or three participants ${ }^{83}$ or indoor meetings in a private space. ${ }^{84}$ The Committee has also been critical of varying requirements being imposed in different regions, provinces, cities etc. ${ }^{85}$

The Committee has regarded prior notification requirements as a de facto interference with the right to freedom of peaceful assembly, requiring justification according to the principles of necessity and proportionality noted above: '.. as the State party has imposed a procedure for organizing mass events, it has effectively established restrictions on the exercise of the rights to freedom of expression and assembly ... ${ }^{86}$ In addition, even if States may legitimately introduce a system of notification to reconcile competing interests, it 'must not operate in a way that is incompatible with the object and purposes of Articles 19 and 21 of the Covenant. ${ }^{87}$ Drawing on more recent jurisprudence of the European Court of Human Rights, the Committee

\footnotetext{
${ }^{80}$ Eg Human Rights Committee, 'Concluding observations on the second periodic report of Thailand' (25 April 2017) UN Doc CCPR/C/THA/CO/2, para 25 (detainees reportedly compelled to sign a written agreement not to travel abroad and refrain from expressing political views - "failure to comply involved the risk of up to two years of imprisonment.'); Human Rights Committee, 'Concluding observations on the second periodic report of Cambodia' (27 April 2015) UN Doc CCPR/C/KHM/CO/2, para 22 (the practice of requiring demonstrators to thumbprint documents pledging to refrain from future demonstrations).

${ }^{81}$ Communication No 2147/2012, Melnikov v Belarus, Views adopted 14 July 2017, para 8.8.

${ }^{82}$ See, by way of example, the US case of Five Borough Bicycle Club v City of New York, 684 F. Supp. 2d 423 (2010).

${ }^{83}$ Eg Kim v Uzbekistan, Views adopted 4 April 2018, UN Doc CCPR/C/122/D/2175/2012, para 13.7.

${ }^{84}$ Eg. Lozenko v Belarus, Views adopted 24 October 2014, UN Doc CCPR/C/112/D/1929/2010, para 7.7.

${ }^{85}$ Human Rights Committee, 'Concluding observations on the initial report of Indonesia' (21 August 2013) UN Doc CCPR/C/IDN/CO/1, para 28 (difference between Papua, which has no permit requirement, and other provinces).

${ }^{86}$ Eg Kivenmaa v Finland, Views adopted 31 March 1994, CCPR/C/50/D/412/1990, para. 9.2 (noting also that, in this case, the State party unsuccessfully sought to rely on jurisprudence of the European Court of Human Rights to argue, at para 7.8, 'that the right of public assembly is not restricted by the requirement of a prior notification to the police'); Govsha, Syritsa and Mezyak v Belarus, Views adopted 27 July 2012, UN Doc CCPR/C/105/D/1790/2008, para 9.2.

${ }^{87}$ Eg Youbko v Belarus, Views adopted 17 March 2014, CCPR/C/110/D/1903/2009, para 9.5.
} 
has held that 'while a system of prior notices may be important for the smooth conduct of public demonstrations, their enforcement cannot become an end in itself. ${ }^{88}$

The Committee has often been critical of authorization requirements ${ }^{89}$ (including their frequent refusal ${ }^{90}$ and the absence of effective remedies in such cases), ${ }^{91}$ though has not yet ruled that authorization requirements are simply incompatible with Article $21 .{ }^{92}$ That said, the Committee's preference for notification over authorization is manifestly clear - it has observed how notification requirements can sometimes operate as de facto authorization requirements, ${ }^{93}$ or otherwise entail unnecessary bureaucratic burdens for those seeking to exercise the right to freedom of peaceful assembly. ${ }^{94}$ In this regard, it is important to note that even apparently neutral procedures may impact differently on different groups depending on their prior history with the authorities. For example, as Chua and Gilbert have noted, Sexual Orientation and Gender Identity (SOGI) minorities in Myanmar, 'distrust the police and find the bureaucratic process intimidating.' Moreover, '[b]ecause LGBT rights groups are generally unregistered, applying for permission also risks prosecution under laws restricting freedom of association... ${ }^{95}$

Notification procedures should always be implemented with a view to facilitating the exercise of the right (so that where a notification contains incomplete information, the

${ }^{88}$ Eg Popova v The Russian Federation, Views adopted 6 April 2018, UN Doc CCPR/C/122/D/2217/2012, para 7.5 (citing ECtHR, Annenkov and others v Russia, Application no 31475/10, judgment of 25 October 2017, para $131(\mathrm{~d}))$.

${ }^{89}$ Eg Human Rights Committee, 'Concluding Observations on the fifth periodic report of Belarus' (22 November 2018) UN Doc CCPR/C/BLR/CO/5, para 51.

${ }^{90}$ Eg Human Rights Committee, 'Concluding Observations on the third periodic report of Azerbaijan' (13 August 2009) UN Doc CCPR/C/AZE/CO/3, para 16 (persistent reports of unreasonable restrictions including by refusing to deliver authorizations).

${ }^{91}$ Eg Human Rights Committee, 'Concluding Observations on the initial report of the Kyrgyz Republic' (24 July 2000) UN Doc CCPR/CO/69/KGZ, para 22 ('lack of appeal procedures in the case of denial of permission').

92 The author in Androsenko v Belarus (2016) sought to make precisely this argument. While the Committee did not expressly rule on the permissibility of authorization regimes, it emphasized that the State should seek to facilitate assemblies, and moreover, must explain and justify why 'such restrictions' were necessary and proportionate. Views adopted 30 March 2016, UN Doc CCPR/C/116/D/2092/2011, paras 3.1 and 7.6. See also, Coleman v Australia, Views adopted 17 July 2006, UN Doc CCPR/C/87/D/1157/2003, Concurring opinion of Committee members Mr Nisuke Ando, Mr Michael O’Flaherty and Mr Walter Kälin. By way of comparison, see ACHPR, Guidelines on Freedom of Association and Assembly (2017) 24, para 71. See also, for example, Commission on Human Rights, Republic of the Philippines, 'On General comment No. 37 Article 21: right of peaceful assembly' (February 2020). Available at

<https://www.ohchr.org/Documents/HRBodies/CCPR/GCArticle21/NHRI_Philippines_Commission_on_Huma n_Rights_PH.docx>

${ }^{93}$ Eg Republic of Korea, 'Concluding observations on the fourth periodic report of the Republic of Korea' (3 December 2015) CCPR/C/KOR/CO/4, para 52; Human Rights Committee, 'List of issues to be taken up in connection with the consideration of the second periodic report of Hong Kong's Special Administrative Region of the People's Republic of China' (7 December 2005) UN Doc CCPR/C/HKG/Q/2, para 14 ('police authorities have used the "notice of no objection" procedure under the Public Order Ordinance to make it more difficult for groups to obtain permissions for marches, demonstrations and rallies').

${ }_{94}$ Eg Human Rights Committee, 'Concluding Observations on the initial periodic report submitted by the Maldives' (31 August 2012) UN Doc CCPR/C/MDV/CO/1, para 23 (concern that 'the "Regulation concerning Assembly", requires at least three persons representing the organizers of public assemblies to submit a written form fourteen days in advance'). Similarly, Govsha, Syritsa and Mezyak v Belarus, Views adopted 27 July 2012, UN Doc CCPR/C/105/D/1790/2008, para 2.4(a) (the authors did not indicate in the application their respective years of birth, nationality and a purpose for the meeting'); Poliakov v Belarus, Views adopted 17 July 2014, UN Doc CCPR/C/111/D/2030/2011, para 8.3 (" "the burdensome requirements of securing three separate written commitments from three different administrative departments ... might have rendered illusory the author's right to demonstrate.')

${ }^{95}$ L J Chua and D Gilbert, 'Sexual Orientation and Gender Identity Minorities in Transition: LGBT Rights and Activism in Myanmar' (2015) 37 Hum Rts $Q 10$. 
authorities should make efforts to obtain the necessary information before either the organizers are regarded as not having satisfied the notification requirements or conditions are imposed on the assembly). ${ }^{96}$ Furthermore, criminal penalties should not be imposed on participants for failing to provide prior notification. ${ }^{97}$ It is in this regard that domestic laws must also recognize an exemption for spontaneous assemblies - those that are 'direct responses to current events" and which could not therefore be notified within the requisite timeframe. ${ }^{99}$ The imposition of liability on assembly participants for mere participation in an 'unlawful assembly' commonly arises because the notification requirement contains no such exemption for either small and entirely innocuous assemblies ${ }^{100}$ or for spontaneous demonstrations. ${ }^{101}$ Such legislative foibles are again symptomatic of a managerial disposition that eschews any form of spontaneity.

\section{'Traffic logic' and the Advocacy of Hatred: Permissible Grounds for Restriction?}

It is well-established in the Committee's jurisprudence that ' $[\mathrm{t}]$ he right to freedom of peaceful assembly $\ldots$ is not absolute but may be subject to limitations in certain situations .... 102 However, it is equally well recognized that the right should not be subject to restrictions on grounds other than those permitted by the Covenant. ${ }^{103}$ Moreover, State parties must provide relevant reasons to justify the necessity of any limitation, explaining how, in practice, an assembly would impact upon the legitimate grounds relied upon. ${ }^{104}$ Within the confines of this article - and directed by the issues arising in the Committee's Concluding Observations on

\footnotetext{
${ }^{96}$ Eg Sekerko v Belarus, Views adopted 28 October 2013, UN Doc CCPR/C/109/D/1851/2008, paras 2.4, 7.2 and 9.7; Poliakov v Belarus, Views adopted 17 July 2014, UN Doc CCPR/C/111/D/2030/2011, para 8.3: ‘... the State party did not explain why the author was not given the opportunity to amend his request to carry out a demonstration and add details that were not fully specified in the original request.'

${ }^{97}$ Human Rights Committee, 'Concluding observations on the second periodic report of Thailand' (25 April 2017) UN Doc CCPR/C/THA/CO/2, para 39.

${ }^{98}$ Draft General Comment No 37, paras 16 and 82 (November 2019).

${ }^{99}$ Eg Popova v The Russian Federation, Views adopted 6 April 2018, UN Doc CCPR/C/122/D/2217/201, para

7.5. Human Rights Committee, 'Concluding observations on the fourth periodic report of Switzerland' (22 August 2017) UN Doc CCPR/C/CHE/CO/4, para 49.

${ }^{100}$ By way of example, see Thai Civil Society Organizations (with support of CCPR Centre), 'Joint submission to the UN Human Rights Committee for the drafting of its General Comment No.37 on Article 21 (right of peaceful assembly) of the ICCPR' (February 2020), paras 14-15. Available at:

<https://www.ohchr.org/Documents/HRBodies/CCPR/GCArticle21/NGO_Thai_Civil_Society_Orgs_.docx>

${ }^{101}$ Eg Forum-Asia, 'Instruments of Repression: A Regional Report on the Status of Freedoms of Expression, Peaceful Assembly, and Association in Asia - A Report on Repressive Laws in Asia' (2018), 104-117. Available at:

<https://www.forum-asia.org/uploads/wp/2019/02/Instruments-of-Repressions-final-edited.pdf>; Human Rights Committee, 'Concluding observations on the third periodic report of Hong Kong, China' (29 April 2013) UN Doc CCPR/C/CHN-HKG/CO/3, para 10; Justice Centre Hong Kong, 'Comments on the Human Rights Committee's Draft General Comment No. 37 on Article 21: Right of Peaceful Assembly’ (February 2020) Available at:

<https://www.ohchr.org/Documents/HRBodies/CCPR/GCArticle21/NGO_Justice_Centre_Hong_Kong.docx>; UNSR FoAA, 'Report of the Special Rapporteur on the rights to freedom of peaceful assembly and of association on his mission to the Republic of Korea' (15 June 2016) UN Doc A/HRC/32/36/Add.2, para 23. ${ }^{102}$ Eg Belyazeka v Belarus, Views adopted 23 March 2012, UN Doc CCPR/C/104/D/1772/2008, para 11.7. ${ }^{103}$ Eg Human Rights Committee, 'Concluding observations on the third periodic report of Vietnam' (29 August 2019) UN Doc CCPR/C/VNM/CO/3, para 48; Human Rights Committee, 'Concluding observations on the sixth periodic report of Mongolia' (22 August 2017) UN Doc CCPR/C/MNG/CO/6, paras 11-12; Human Rights Committee, 'Concluding observations on the fourth periodic report of the Republic of Korea' (3 December 2015) UN Doc CCPR/C/KOR/4, para 53; Human Rights Committee, 'Concluding observations on the second periodic report of Cambodia' (27 April 2015) UN Doc CCPR/C/KHM/CO/2, para 22.

${ }^{104}$ Eg Kovalenko v Belarus, Views adopted 17 July 2013, UN Doc CCPR/C/108/D1808/2008, para 8.6 (Article 19) and para 8.8 (Article 21).
} 
State reports from the Asia Pacific region - two issues are singled out for brief discussion here - the need to resist traffic based arguments that favour the restriction of peaceful assemblies, and the need for caution in classifying entire assemblies as advocating hatred.

\section{Resisting 'traffic logic'}

One of the greatest threats to the effective realization of the right of peaceful assembly lies in a functional understanding of public places - in particular, the idea that public roads are exclusively for vehicular traffic rather than also a place for participation. ${ }^{105}$ This is an aspect where, again, domestic assembly laws tend to prioritize the management of assemblies over their facilitation. Consider, for example, the Myanmar Right to Peaceful Assembly and Peaceful Procession Act 2011, section 12(c) of which states that assemblies 'must not obstruct or disturb vehicles, pedestrians, and people.' ${ }^{106}$

Nicholas Blomley has urged resistance to 'traffic logic' which, he argues, reconceives of roads and streets as 'transport corridors' and citizens as mere 'traffic participants'. ${ }^{107}$ Similarly, the assumed logic of residential spaces may tend towards assemblies being permitted only during daylight hours or subject to noise restrictions. These spatial logics commonly operate to exclude what are perceived as unruly or undesirable uses (vagrancy, busking, revelry, protest and dissent etc) and seek to reserve particular spaces for seemingly benign purposes (consumption, movement, recreation, education etc). ${ }^{108}$

'Traffic logic' prevails in many countries both within and beyond the Asia Pacific region. In this regard, the Human Rights Committee has expressed particular concern about legal provisions permitting restrictions on the basis of disruption to traffic, ${ }^{109}$ emphasizing that national authorities must explain how a particular demonstration would actually hinder traffic or the movement of pedestrians. ${ }^{110}$ Similar concerns have also been emphasized by the UN Special Rapporteur on the Rights to Freedom of Peaceful Assembly and of Association. ${ }^{111}$ In this regard, the draft text of General Comment No 37 emphasizes that '[p]eaceful assemblies are in some cases inherently disruptive' 112 and '[m]ere disruption of vehicular or pedestrian movement or daily activities does not amount to violence. ${ }^{113}$ Indeed, 'an assembly that remains peaceful but which nevertheless causes a high level of disruption, such as the extended blocking of traffic, may be dispersed ... only if the disruption is "serious and sustained"., 114

\footnotetext{
${ }^{105}$ Eg Spanish Constitutional Court, judgment STC 193/2011 of 12 December 2011.

106 For an English translation of the 2011 Act, see <https://www.burmalibrary.org/docs 15/2011Peaceful_Assembly_and_Procession_Act-en.pdf>

${ }^{107}$ N Blomley, Rights of Passage: Sidewalks and the Regulation of Public Flow (Routledge 2010).

${ }^{108}$ H Fenwick and M Hamilton, 'Freedom of protest and assembly' in Fenwick on Civil Liberties and Human Rights ( $5^{\text {th }}$ edn, Routledge 2017) 601.

${ }^{109}$ Human Rights Committee, 'List of issues in relation to the fourth periodic report of the Republic of Korea' (28 April 2015) UN Doc CCPR/C/KOR/Q/4, para 26 '(b) the use of the General Obstruction of Traffic provision and of article 314 of the Criminal Code on obstruction of business, against demonstrators'; Human Rights Committee, 'Concluding observations on the second periodic report of the Republic of Korea' (1 November 1999) UN Doc CCPR/C/79/Add.114, para 18 'The prohibition of all assemblies on major roads in the capital would appear to be overbroad';

${ }^{110}$ Stambrovsky v Belarus, Views adopted 24 October 2014, UN Doc CCPR/C/112/D/1987/2010, para 7.6. In this case, the author claimed (at para 3 ) that the authorities had 'invented' grounds of hindering traffic in relation to proposed one-person picket in a pedestrian area.

${ }^{111}$ UN Doc A/HRC/32/36/Add.2 Report of the Special Rapporteur on the rights to freedom of peaceful assembly and of association on his mission to the Republic of Korea, para 39 'the indictment of hundreds of participants for the criminal offence of general obstruction of traffic.'

112 Para 50.

${ }^{113}$ Para 17.

${ }^{114}$ Revised Draft General Comment No 37 (November 2019), para 96 citing, 'Joint report of the Special Rapporteur on the rights to freedom of peaceful assembly and of association and the Special Rapporteur on
} 


\section{Advocacy of hatred}

In its 2014 Concluding Observations in relation to Japan, the Human Rights Committee expressed 'concern at the high number of extremist demonstrations authorized' and concluded that the State should prohibit all propaganda advocating racial superiority or hatred that incites discrimination, hostility or violence, and should prohibit demonstrations that are intended to disseminate such propaganda. ${ }^{115}$ More general concerns were previously stated in the Bangkok Declaration over 'manifestations of racial discrimination, racism, apartheid, ... as well as the recent resurgence of neo-nazism, xenophobia and ethnic cleansing. ${ }^{116}$ Indeed, Article 20(2) ICCPR and Article 4 CERD $^{117}$ could potentially be read as mandating the wholesale prohibition of assemblies advocating hatred that constitutes incitement to discrimination or hostility. ${ }^{118}$ In this regard, CERD General Recommendation No 35 makes clear that the requirements of Article 4 CERD apply to racist hate speech in whatever forms it manifests itself, including 'behaviour at public gatherings, including sporting events'. ${ }^{119}$ Indeed, in its Concluding Observations on State Reports, the CERD Committee has addressed the subject of assemblies involving hate speech and/or 'extremist' groups on a number of occasions. ${ }^{120}$

Pulling against these restrictive inclinations, the Human Rights Committee has emphasized that '[f]reedom of assembly protects demonstrations promoting ideas that may be

extrajudicial, summary or arbitrary executions on the proper management of assemblies' (4 February 2016) UN Doc A/HRC/31/66, para 62.

${ }^{115}$ Human Rights Committee, 'Concluding observations on the sixth periodic report of Japan', UN Doc CCPR/C/JPN/CO/6, 20 August 2014, para 12.

${ }^{116}$ Bangkok Declaration (n 24) para 14.

${ }^{117}$ In the case of The Jewish community of Oslo and others v Norway (15 August 2005) UN Doc

CERD/C/67D/30/2003, the CERD held that the acquittal of the leader of a commemorative event near Oslo had violated the rights of the authors - as members of the Jewish community - under Article 4 ICERD.

Significantly, the authors contended (para 3.9) that 'the use of the Nazi salute made clear that the gathering was not peaceful, and, given the Bootboys' record of violence, the commemoration march was frightening, and the incitement to violence evident.' The Committee held (para 10.4) that this constituted incitement at least to racial discrimination, if not to violence.

${ }^{118}$ A separate question arises in relation to whether 'peacefulness' (as a definitional element of the scope of the right) should itself be construed to align with Article 20(2) ICCPR and Article 4 ICERD. The revised draft text of General Comment 37 (November 2019) presents two options (see the bracketed text in paras 22 and 57) one, elevating such factors into the assessment of whether an assembly is peaceful (and thus within the protective scope of Article 21) and the other, reserving such factors to the assessment of whether restrictions might be necessary. On the basis that restrictions ought to be individualized (whereas Option 1 risks legitimizing domestic categorizations of entire assemblies falling within any strand of Article 20(2) and, in turn, their presumptive prohibition) and since any elision of 'scope' with 'grounds for restriction' stands to diminish what the right protects, it is suggested here that the second option is much preferable. Many of the submissions made to the Human Rights Committee on the draft text of General Comment 37 have similarly urged the Committee not to locate Article 20 considerations in the determination of whether an assembly should be regarded as 'peaceful', including Commission on Human Rights, Republic of the Philippines, 'On General Comment No. 37 Article 21: right of peaceful assembly' (February 2020). Available at

<https://www.ohchr.org/Documents/HRBodies/CCPR/GCArticle21/NHRI_Philippines_Commission_on_Huma n_Rights_PH.docx>; and Kyung Sin Park, 'Open Net Korea's comments on the draft General Comment 34 on Right to Peaceful Assembly' (12 February, 2020) Available at:

<https://www.ohchr.org/Documents/HRBodies/CCPR/GCArticle21/NGO_Open_Net_Korea.docx>

${ }^{119}$ CERD/C/GC/35, General Recommendation No. 35, para 7, emphasis added.

${ }^{120} \mathrm{Eg}$ Human Rights Committee, 'Concluding observations on the sixth periodic report of Japan' (20 August 2014) UN Doc CCPR/C/JPN/CO/6, 20 August 2014, para 12. Similarly, Human Rights Committee, 'Concluding observations on the third periodic report of the Czech Republic' (22 August 2013) UN Doc $\mathrm{CCPR} / \mathrm{C} / \mathrm{CZE} / \mathrm{CO} / 3$, para 8; Human Rights Committee, Draft concluding observations on the fifth periodic report of Belgium' (16 November 2010) UN Doc CCPR/C/BEL/CO/5, para 22. 
regarded as annoying and offensive by others', ${ }^{121}$ and that the right to freedom of peaceful assembly also entails the possibility of organizing and participating in a gathering "with the intent to support or disapprove one or another particular cause. ${ }^{122}$ The Human Rights Committee has also emphasized that Article 20(2) is narrowly crafted so as not to unduly infringe upon other Covenant rights (and article 19 in particular). ${ }^{123}$ In addition, the CERD has recognized that, 'measures to monitor and combat racist speech should not be used as a pretext to curtail expression of protest at injustice, social discontent or opposition.' ${ }^{124}$ Moreover, under Article 4 ICERD, 'the criminalization of forms of racist expression should be reserved for serious cases'. ${ }^{125}$

While the precise boundaries here are unclear, it is certainly not as straightforward as classifying all assemblies with links to particular ideologies (such as the far-right) as falling outwith the protective scope of Article $21 .{ }^{126}$ Rather than classifying an entire assembly as falling within the impugned categories set out in Article 20(2) ICCPR and Article 4 ICERD, there ought to be individualized assessment of conduct. ${ }^{127}$ As the Revised draft text of General Comment 37 emphasizes, 'action should be taken in such cases against the individual perpetrators, rather than against the assembly as a whole. ${ }^{128}$ Furthermore, the abuse of rights clause in Article 5 ICCPR precludes someone from relying on their right of peaceful assembly 'to engage in any activity or perform any act aimed at the destruction of' other Covenant rights 'or at their limitation to a greater extent' than is otherwise provided for in the Covenant.

\section{Challenging Structural Problems in the Legal Framework}

It has been argued thus far that domestic laws can operate in a manner that is detrimental to the right of peaceful assembly by underpinning a regulatory approach premised on the management of assemblies. In this light, it is important to think about how structural problems with the domestic legal framework might potentially be challenged.

In its assembly jurisprudence, the Committee has, at different times cautiously 'invited' States 'to review' legislation 'with a view to aligning it with the requirements of Article $21,{ }^{129}$ held that a State party 'should review its legislation ... and its application' 130 either 'to prevent

\footnotetext{
${ }^{121}$ Eg Alekseev v Russian Federation, Views adopted 25 October 2013, UN Doc CCPR/C/109/D/1873/2009, para 9.6.

${ }^{122}$ Eg Praded v Belarus, Views adopted 10 October 2014, UN Doc CCPR/C/112/D/2029/2011, para 7.4.

${ }^{123} \mathrm{Eg}$ Rabbae, A.B.S. and N.A. $v$ the Netherlands, Views adopted 14 July 2016, CCPR/C/117/D/2124/2011, para 10.4 .

${ }^{124}$ ICERD, 'General Recommendation No 35: Combating racist hate speech' (26 September 2013) UN Doc CERD/C/GC/35, para 20.

125 ibid para 12.

${ }^{126}$ Cf N Alkivaiadou 'The Far-Right in International and European Law' (Routledge, 2019) drawing on Article 4 ICERD to suggest that 'it can be argued that any far-right assemblies are not protected by this freedom.'

${ }^{127}$ As stated by the European Court of Human Rights, for example, '... the freedom to take part in a peaceful assembly ... is of such importance that it cannot be restricted in any way ... so long as the person concerned does not himself commit any reprehensible act on such an occasion.' ECtHR, Ezelin v France, Application No 11800/85, judgment of 26 April 1991, para 53.

${ }^{128}$ Revised Draft General Comment No 37 (November 2019), para 57.

${ }^{129}$ Eg Levinov v Belarus, Views adopted 19 July 2012, UN Doc CCPR/C/105D/1867/2009, 1936, 1975,1977 1981, 2010/2010, para 12 (without expressly invoking the second paragraph of article 2, and whilst holding the author's freestanding article 2 complaint to be inadmissible - para 9.3); Poliakov v Belarus, Views adopted 17 July 2014, UN Doc CCPR/C/111/D/2030/2011, para 10 (holding the author's freestanding article 2 complaint to be inadmissible - para 7.4).

${ }^{130}$ Eg Olechkevitch v Belarus, Views adopted 18 March 2013, UN Doc CCPR/C/107/D/1785/2008, para 10.
} 
similar violations in the future" ${ }^{\prime 31}$ or 'with a view to ensuring that the rights under Articles 19 and 21 ... may be fully enjoyed in the State party'. ${ }^{132}$

The Committee has been slightly more emphatic in critiquing domestic laws governing assemblies in its Concluding Observations on State Reports. ${ }^{133}$ Indeed, for anyone seeking to challenge structural deficiencies in the domestic legal framework, it is through the process of the review of periodic State reports that the Committee has greatest latitude to review domestic laws in abstracto (i.e. without the need to confine its critique of the law to the specific facts of a particular case). While the Committee has sometimes merely suggested that the implementation of domestic laws must be in conformity with the Covenant, ${ }^{134}$ the Committee has sometimes also urged States to revise the domestic legal framework, ${ }^{135}$ including laws and regulations governing the use of force. ${ }^{136}$

Additionally (for those in countries that have ratified the First Optional Protocol) there is scope to frame individual communications not solely in relation to Article 21, but also to invoke Articles 2(2) ${ }^{137}$ and 2(3)(a) ${ }^{138}$ in conjunction with Article 21 arguing that the State has failed to put in place an enabling legal framework and to provide an effective remedy. In this regard, it is notable that some Committee members have questioned whether a finding of a violation of Article 2 adds anything to the protection of the individual ${ }^{139}$ (urging instead that Article 2(2) should never be invoked in conjunction with Article 21 'any more than it can be invoked in isolation'). ${ }^{140}$ Other members have proposed a middle-ground formulation whereby Article 2 would generally not be considered separately unless the failure of a State to observe its

\footnotetext{
${ }^{131}$ Eg Schumilin v Belarus, Views adopted 23 July 2012, UN Doc CCPR/C/105/D/1784/2008, para 11.

${ }^{132}$ Eg Misnikov v Belarus, Views adopted 14 July 2016, UN Doc CCPR/C/117/D/2093/2011, para 11.

${ }^{133}$ Eg Human Rights Committee, 'Concluding observations on the third periodic report of Hong Kong, China'

(29 April 2019) UN Doc CCPR/C/CHN-HKG/CO/3, para 10.

${ }^{134}$ Eg Human Rights Committee, 'Concluding observations on the second periodic report of Cambodia' (27 April 2015) UN Doc CCPR/C/KHM/CO/2, para 22. Notably, in its 1999 Concluding Observations on Hong Kong, the Committee stated that the much criticized Public Order Ordinance should be reviewed by the Hong Kong Special Administrative Region to 'bring its terms into compliance with article 21 of the Covenant' (Human Rights Committee, 'Concluding observations on the fifth periodic report of Hong Kong' (15 November 1999) UN Doc CCPR/C/79/Add.117, para 19). However, by 2013, the Committee had downgraded its recommendation from fundamental reform to ensuring merely 'that the implementation of the Public Order Ordinance is in conformity with the Covenant (Human Rights Committee, 'Concluding observations on the third periodic report of Hong Kong, China' (29 April 2013) UN Doc CCPR/C/CHN-HKG/CO/3, para 10). ${ }^{135}$ Human Rights Committee, 'Concluding observations on the initial report of the Lao People's Democratic Republic (23 November 2018) UN Doc CCPR/C/LAO/CO/1, paras 33-34; Human Rights Committee, 'Concluding observations on the initial periodic report submitted by the Maldives' (31 August 2012) UN Doc CCPR/C/MDV/CO/1, para 23.

${ }^{136}$ Human Rights Committee, 'Concluding observations on the fourth periodic report of the Republic of Korea' (3 December 2015) UN Doc CCPR/C/KOR/4, para 53; Human Rights Committee, 'Concluding observations on the initial periodic report submitted by the Maldives' (31 August 2012) UN Doc CCPR/C/MDV/CO/1, para 23.

${ }^{137}$ Each State Party undertakes 'to take the necessary steps, in accordance with its constitutional processes and with the provisions of the present Covenant, to adopt such laws or other measures as may be necessary to give effect to the rights recognized in the present Covenant.'

${ }^{138}$ Each State Party undertakes '(a) To ensure that any person whose rights or freedoms as herein recognized are violated shall have an effective remedy, notwithstanding that the violation has been committed by persons acting in an official capacity.'

${ }^{139}$ Kuznetsov et al v Belarus, Views adopted 24 July 2014, UN Doc CCPR/C/111/D/1976/2010, Joint concurring opinion of Committee members, Gerald L. Neuman, Anja Seibert-Fohr, Yuji Iwasawa and Konstantine Vardzelashvili, para 3.

140 ibid para 2. Similarly, Mikhalchenko v Belarus, Views adopted 22 July 2015, UN Doc

CCPR/C/114/D/1982/2010, Individual opinion of Committee Members Anja Seibert-Fohr and Yuji Iwasawa (concurring).
} 
obligations was 'the proximate cause of a distinct violation of the Covenant directly affecting the individual who claims to be a victim.' 141

Given, however, that inadequacies in the legal framework frequently underlie domestic violations of the right of peaceful assembly, it is argued here (and as proposed by former Committee member, Sarah Cleveland) that the Committee ought to appropriately recognize 'structural violations' whereby 'persistent failure by a State party to conform its laws to give effect to rights under the Covenant constitutes a failure to comply with Article 2(2) and should ... be understood to give rise to a "distinct violation" of the Covenant. ${ }^{142}$ Furthermore, as has been emphasized in particular by former Committee member, Fabián Salvioli, the finding of a violation of Article 2 should be regarded as a form non-pecuniary reparation where an incompatible law has been adopted. ${ }^{143}$ As tersely stated in the separate concurring opinion of Fabián Salvioli, Yuval Shany and Víctor Rodríguez Rescia in Olechkevitch v Belarus (2013), rather than "stating in general terms that the State "should review its legislation"" it would be "more appropriate for the Committee to indicate clearly that the State should repeal legislation that is incompatible with the Covenant ... and ensure that the provisions that replace those instruments are fully consistent with the rights laid down in the Covenant. ${ }^{144}$ Arguing that the Committee should have found a violation of Article 2(2) in conjunction with Article 19, the concurring opinion noted that:

'The international responsibility of the State may be engaged by the action of the legislative branch or any other branch of government that has legislative power under the country's legal system. The failure to fulfil the obligation laid down in article 2, paragraph 2, of the Covenant engages such responsibility by virtue of an act (adopting incompatible legislation) or omission (not bringing national legislation into line with the provisions of the Covenant following its ratification). ${ }^{145}$

\section{Conclusion}

The challenges facing the protection of the right of peaceful assembly in the Asia-Pacific region are as widely varied and diverse as the political and legal terrain of the region itself. The right of peaceful assembly has enabled people to rally together and build powerful movements, including those seeking to expose corruption and electoral malpractice, champion gender equality and pursue environmental justice. It is only by being able to join together freely with others that a movement can begin to grasp the intensity of support it enjoys.

Too often, however, the potency of the right of assembly is neutralized when State authorities prioritize the management (and control) of assemblies rather than their facilitation

\footnotetext{
${ }^{141}$ Poliakov v Belarus, Views adopted 17 July 2014, UN Doc CCPR/C/111/D/2030/2011, para 7.4. The Poliakov phrasing has been criticized for introducing a test predicated on 'vague notions' ('proximate cause', 'distinct violation') - see, Kuznetsov (n 36) Joint concurring opinion, para 2.

${ }^{142}$ Individual opinion of Committee Member Sarah Cleveland (concurring) in Poplavny v Belarus, Views adopted 5 November 2015, UN Doc CCPR/C/115D/2019/2010 and Sudalenko v Belarus, Views adopted 5 November 2015, UN Doc CCPR/C/115/D/2016/2010.

${ }^{143}$ Individual concurring opinion of Mr Fabián Salvioli in Tulzhenkova v Belarus, Views adopted 26 October 2011, UN Doc CCPR/C/103/D/1838/2008, para 12, noting also General Comment 31, 'The nature of the general legal obligation imposed on States Parties to the Covenant' (29 March 2004) UN Doc CCPR/C/21/Rev.1/Add.13.

${ }^{144}$ Olechkevitch v Belarus, Views adopted 18 March 2013, UN Doc CCPR/C/107/D/1785/2008, Separate opinion, paras 4-7.

145 ibid para 4.
} 
and protection. In many countries, this prophylactic logic is woven into the fabric of the domestic legal framework - affording widely framed discretionary powers to law enforcement officials, creating bureaucratic systems of notification (which operate in a manner more akin to authorization) and imposing onerous penalties (often en masse for mere participation in an 'unlawful assembly'). In short, the right of peaceful assembly is too often regarded as an inconvenience to be controlled and managed, rather than a fundamental right to be protected and facilitated.

The neglected assembly jurisprudence of the UN Human Rights Committee reveals a number of protective principles and State obligations which push back against the neutralizing logic of assembly management. The Committee has generally articulated these obligations in the language of 'respecting and ensuring' and 'facilitating and protecting' the right of assembly. In this light, the forthcoming adoption of General Comment No 37 stands to provide a vital and authoritative reference point - one which will hopefully incentivize and inform future challenges to restrictive laws wherever they are enacted. 